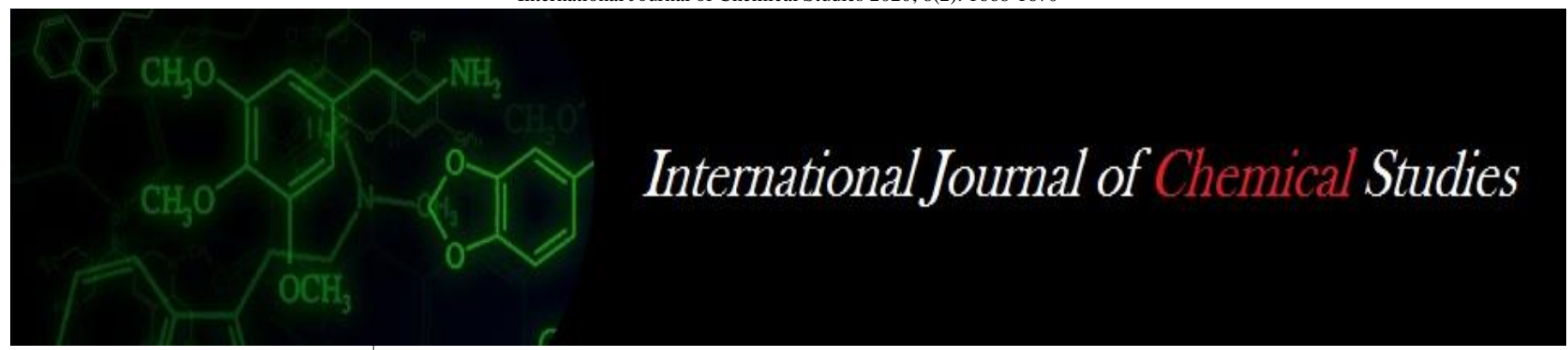

P-ISSN: 2349-8528

E-ISSN: 2321-4902

www.chemijournal.com

IJCS 2020; 8(2): 1668-1670

(C) 2020 IJCS

Received: 01-01-2020

Accepted: 05-02-2020

Dipankar Bharali

Livestock Research Station, Assan

Agricultural University, Mondira,

Kamrup, Assam, India

Kabin Chandra Deka

Department of Animal

Reproduction, Gynaecology \&

Obstetrics, College of Veterinary

Science, AAU, Khanapara,

Guwahati, Assam, India

Bharat Chandra Deka

Department of Anima

Reproduction, Gynaecology \&

Obstetrics, College of Veterinary

Science, AAU, Khanapara,

Guwahati, Assam, India

Keshab Chandra Nath

Department of Animal

Reproduction, Gynaecology \&

Obstetrics, College of Veterinary

Science, AAU, Khanapara,

Guwahati, Assam, India

Ranjan Kumar Biswas

Department of Animal

Reproduction, Gynaecology \&

Obstetrics, College of Veterinary

Science, AAU, Khanapara,

Guwahati, Assam, India

Lakshya Jyoti Dutta

Department of Animal

Reproduction, Gynaecology \&

Obstetrics, College of Veterinary

Science, AAU, Khanapara,

Guwahati, Assam, India

Birendra Kumar Sarmah

Department of Veterinary

Physiology, College of Veterinary

Science, AAU, Khanapara,

Guwahati, Assam, India

Bibeka Nanda Saikia

Department of Animal Nutrition,

College of Veterinary Science,

AAU, Khanapara, Guwahati,

Assam, India
Corresponding Author: Dipankar Bharali

Livestock Research Station, Assam Agricultural University, Mondira,

Kamrup, Assam, India

\section{Concentration of serum estradiol, progesterone and cortisol during biological stress period of normal cyclic and silent Oestrous crossbred cows of Assam}

\author{
Dipankar Bharali, Kabin Chandra Deka, Bharat Chandra Deka, Keshab \\ Chandra Nath, Ranjan Kumar Biswas, Lakshya Jyoti Dutta, Birendra \\ Kumar Sarmah and Bibeka Nanda Saikia
}

DOI: https://doi.org/10.22271/chemi.2020.v8.i2z.9000

\begin{abstract}
The present study was planned to compare the concentration of serum estradiol, progesterone and cortisol level during biological stress period of normal cyclic and silent oestrous cycles of crossbred cows of Assam. Jugular blood samples were collected from ten normal cyclic and ten silent oestrous cows on day 0,10, 17 and 20 of cycles for the present study. These 3 hormones were estimated by using ELISA kit manufactured by LDN GmbH\& Co.KG, Germany, by solid phase enzyme-linked immunosorbent assay. Both estradiol and progesterone concentrations in serum were varied significantly $(P<0.01)$ between days of oestrous cycles of normal and silent oestrous cows. Lowest level of progesterone with concomitant highest level of estradiol was recorded on the day of oestrus. On the other hand, highest concentration of progesterone was found on the day 10 of cycles with lowest concentration of estradiol on day 17 of cycle. The mean levels of cortisol varied significantly between days of cycles with highest level on the day of oestrus.
\end{abstract}

Keywords: Cattle, cortisol, normal oestrous cycle, progesterone, silent oestrous cycle, estradiol

\section{Introduction}

Serum Progesterone plays an essential role in various reproductive functions, including regulating the length of the estrous cycle, maintaining pregnancy. Progesterone is high during the luteal phase and in pregnancy, however the levels decline if the animal fails to conceive. Progesterone has been implicated in inhibiting estrogen secretion and ovulation (Echternkamp et al. 1973 and Henricks, 1971) ${ }^{[1,12]}$. Estradiol in plasma in the cycling cow and heifer play role in expression of estrus and ovulation (Akbar et al., 1974; Chenault et al., 1975 and Dobson, 1978) ${ }^{[2,6,9]}$. Cortisol is considered to be the indicator of biological stress (Cole and Cupps, 1977, Rao and Pandey 1981, Lyimo et al. 2007) ${ }^{[7,17,14]}$ where high milk production and manifestation of reproductive cycles might be associated with oxidative stress (West 2003) ${ }^{[23]}$. Research information in regards to simultaneous modulation pattern of these 3 hormones in high yielding crossbred cows during normal and silent oestrous cycles. Therefore, the present study was carried out to compare the modulation of these 3 hormones in serum in normal cyclic and silent oestrous crossbred cows of Assam during oestrous cycle.

\section{Materials and Methods}

Ethical approval

All applicable institutional ethical guidelines for care and use of animals were followed.

Blood samples were collected from 10 normal cyclic and 10 silent oestrous cows on day 0,10 , 17 and 20 (day 0 of the next cycle) of oestrous cycle and serum was separated. Serum progesterone, oestradiol and cortisol were estimated by using ELISA kits manufactured by LDN GmbH \& Co.KG, Germany, by solid phase enzyme-linked immunosorbent assay. The statistical analysis of the experimental data was carried out using standard software version (SPSS20) 


\section{Results and Discussion}

The mean concentrations of serum estradiol, progesterone and cortisol in normal cyclic and silent oestrous cows on day 0 , 10, 17 and 20 have been presented in Table 1. The mean serum estradiol concentration in silent oestrous and normal oestrous cows on different days of oestrous cycle i.e. on day $0,10,17$ and 20 were $40.13 \pm 0.64 \& 39.34 \pm 1.11 ; 24.24 \pm$ $2.00 \& 20.00 \pm 0.82 ; 18.12 \pm 1.74 \& 14.52 \pm 0.79 ;$ and 40.15 $\pm 0.73 \& 38.35 \pm 0.68 \mathrm{pg} / \mathrm{ml}$, respectively. Progesterone level were $0.33 \pm 0.03 \& 0.32 \pm 0.04 ; 4.74 \pm 0.41 \& 4.47 \pm$ $0.41 ; 3.67 \pm 0.21 \& 3.08 \pm 0.33$ and $0.43 \pm 0.02 \& 0.42 \pm 0.02$ $\mathrm{ng} / \mathrm{ml}$, respectively while cortisol level were $29.58 \pm 0.83 \&$ $28.48 \pm 1.08 ; 25.46 \pm 0.93 \& 24.28 \pm 0.67 ; 22.77 \pm 1.22 \&$ $21.51 \pm 0.78$ and $30.08 \pm 0.76 \& 27.62 \pm 0.99 \mathrm{nM} / \mathrm{L}$, in silent oestrous and normal oestrous cows on different days of oestrous cycle i.e. on day $0,10,17$ and 20, respectively.

Both oestradiol and progesterone concentrations in serum varied significantly $(P<0.01)$ between days of oestrous cycle of both types of cyclic cows of the present study, but no significant variation was noticed between the groups. The estradiol was significantly highest with lowest serum progesterone level on the day of oestrus of cycles while reversal variation of steroids being highest concentration of oestradiol with lowest progesterone was recoreded on day 0 and 17 of cycles. Similar cyclic variation of steroids were also reported by (Dorbrwolski et al. 1973, Kang et al. 1994, Shukla et al. 2000, Bhuyan et al. 2004, Deka et al. 2007 and Bonia and Goswami (2011) ${ }^{[10,13,19,5,8,4]}$. Serum progesterone level above $2 \mathrm{ng} / \mathrm{ml}$ at mid luteal phase could be considered as normal as reported by Nakao et al. (1983a) ${ }^{[16]}$. In agreement to the present result Stevenson (1997) ${ }^{[20]}$ also opined that the presence of corpus luteum associated with increase concentration of progesterone when estrogen level was varied towards mid luteal stages in cows.

Table 1: The concentration (mean \pm s.e.) of serum estradiol, progesterone and cortisol in normal cyclic and silent oestrous cows on different days of cycles

\begin{tabular}{|c|c|c|c|c|c|}
\hline \multirow{2}{*}{ Parameter } & \multirow{2}{*}{ Types cows } & \multicolumn{4}{|c|}{ Days of oestrous cycle } \\
\hline & & Day 0 & Day 10 & Day 17 & Day 20 \\
\hline \multirow{2}{*}{ Estradiol (pg / ml) } & Normal cyclic & $39.34^{\mathbf{A}} \pm 1.11$ & $20.00_{\mathrm{ad}^{\mathrm{B}}}^{\mathrm{B}} \pm 0.82$ & $14.52 \mathrm{ad}^{\mathrm{C}} \pm 0.79$ & $38.35 \mathrm{a}^{\mathrm{A}} \pm 0.68$ \\
\hline & Silent oestrus & $40.13^{\mathbf{A}} \pm 0.64$ & $24.24_{b c}{ }^{B} \pm 2.00$ & $18.12_{b c}{ }^{C} \pm 1.74$ & $40.15 \mathrm{ab}^{\mathrm{A}} \pm 0.73$ \\
\hline \multirow{2}{*}{ Progesterone $(\mathrm{pg} / \mathrm{ml})$} & Normal cyclic & $0.32^{\mathbf{A}} \pm 0.04$ & $4.47^{\mathbf{B}} \pm 0.41$ & $3.08^{\mathrm{C}} \pm 0.33$ & $0.42^{\mathrm{A}} \pm 0.02$ \\
\hline & Silent oestrus & $0.33^{\mathrm{A}} \pm 0.03$ & $4.74^{\mathbf{B}} \pm 0.41$ & $3.67^{\mathrm{C}} \pm 0.21$ & $0.43^{\mathrm{A}} \pm 0.02$ \\
\hline \multirow{2}{*}{ Cortisol (nM/L) } & Normal cyclic & $28.48 \mathrm{abc}^{\mathrm{A}} \pm 1.08$ & $24.28 \mathrm{ab}^{\mathrm{B}} \pm 0.67$ & $21.51_{\mathrm{b}}^{\mathrm{C}} \pm 0.78$ & $27.62_{\mathrm{a}}^{\mathrm{A}} \pm 0.99$ \\
\hline & Silent oestrus & $29.58 \mathrm{ab}^{\mathrm{A}} \pm 0.83$ & $25.46_{\mathrm{a}}^{\mathrm{B}} \pm 0.93$ & $22.77_{\mathrm{ab}}^{\mathrm{C}} \pm 1.22$ & $30.08 \mathrm{ab}^{\mathrm{A}} \pm 0.76$ \\
\hline
\end{tabular}

Means with different subscripts (a,b,c) within a column and superscripts $(\mathrm{A}, \mathrm{B}, \mathrm{C})$ within a row differ significantly $(P<0.01)$.

The analysis of variance revealed that means level of serum cortisol was significantly higher $(P<0.01)$ among different days of oestrous cycle in silent oestrus and normal cyclic cows. In the present study the mean concentration of cortisol in serum ranged from 22.77 to $30.08 \mathrm{nM} / \mathrm{L}$ in silent oestrous crossbred cows and the values ranged from 21.51 to $28.48 \mathrm{nM}$ / $\mathrm{L}$ in normal oestrous cows. The highest concentration was recorded on day of oestrus and lowest value was recorded on day 17 of oestrous cycle in both the silent and normal oestrous cows. The pattern of changes of cortisol levels in both types of oestrous cycle was in agreement with the findings of Rao and Pandey (1981) ${ }^{[17]}$, Singh et al. (2008) ${ }^{[19]}$, Bonia and Baishya (2011) ${ }^{[3]}$ and Bonia and Goswami (2011) [4]. The variation of levels of cortisol at oestrus might be due to biological stress factors like restlessness with wide range of body activities (McDonald, 1980) ${ }^{[15]}$. Tanaka et al. (2008) ${ }^{[21]}$ observed that there was relationship between milk production and oxidative stress markers concentration in plasma with concomitant variations of estrogen, progesterone and cortisol during the time of onset of oestrus (Walker et al., 2008) [22] and the low levels of this hormone in serum during luteal and follicular phases of cycles of the present study might be reflection of adaptation to the environment and some mechanism to prevent high metabolic heat (Adeyemo et al., 1981) ${ }^{[1]}$.

\section{References}

1. Adeyemo O, Heatgth E, Adadevoh BK, Steinbach J. Plasma cortisol index in Bos tarus and Bos incus heifers in seasonal tropical climate. Journal of Dairy Science 1981; 64 (7):1586-96.

2. Akbar AM, Reichert LE, Dunn TG, Kaltenbach CC, Niswender GD. Serum levels of follicle stimulating hormone during the bovine estrous cycle. J Anita. Sci. 1974; 39:360.
3. Bonia KK, Baishya N. Therapeutic management versus biological constituents of sub- oestrous crossbred cows of Asom. Indian J Anim. Sci. 2011; 81(4):362-66.

4. Bonia KK, Goswami J, Serum $17 \quad \beta$ oestradiol, progesterone and cortisol level during biological stress period of normal and sub- oestrous cycles of crossbred cattle of Asom. Indian J Anim. Sci. 2011; 81(7):676-678.

5. Bhuyan S, Chakravarty $\mathrm{P}$, Sharmah BC, Barua KK, Bordoloi PK, Sharma S. Serum17 $\beta$-estradiol and progesterone concentration study in cyclic local and crossbred (Jersey X Local) cows of Assam. National seminar on radiation and biochemical technique in Animal Science and human health hazard, 2004, 18-19.

6. Chenault JR, Thatcher WW, Kalra PS, Abrams RM, Wilcox CJ. Transitory changes in plasma progestins estradiol and luteinizing hormone approach ovulation in the bovine. J. Dairy Sci. 1975; 58:709.

7. Cole HH, Cupps PT. Reproduction in domestic animals. 1977; $3^{\text {rd }}$ edn. Academic Press, New York, San Francisco, London.

8. Deka KC, Borgohain BN, Nath KC, Goswami J, Biswas RK, Das PK. A comparative appraisal of serum progesterone level during oestrou cycle in normal and repeat breeder crossbred cows with ovulatory problem. Indian J Animal Reprod. 2007; 28(2):83-85.

9. Dobson H. Plasma gonadotropins and oestradiol during oestrus in the cow. J Reprod. Fert. 1978; 52:51.

10. Dorbrwolski W, Snchchowski M, Stazkiewiez M. The level of prohgesterone in the peripheral blood of cow during the oestrous cycle. Polskis Archwum Weterinryine 16(4):671-76 (fide Animal Breeding Abstract. 1973; 43:1060.

11. Echternkamp SE, Hansel W. Con- current changes in bovine plasma hormone levels prior to and during the 
first postpartum estrous cycle. J Anim. Sci. 1973; 37:1362.

12. Henricks DM, Dickey JF, Hill JR. Plasma estrogen and progesterone levels in cows prior to and during estrus. Endocrinology. 1971; 89:1350.

13. Kang B, Choi H, Son C, Chon H. Progesterone assay as an aid for improving reproductive efficiency in dairy cattle. 2. Use of plasma or milk progesterone profiles for differential diagnosis of ovarian cysts. Korean Journal of Veterinary Research. 1994; 34(1):181-88.

14. Lyimo Z, Nielen M, Ouweltjes W, Kruip T, Eerdenburg F. Relationship among estradiol, cortisol intensity of estrous behavior in dairy cattle. Theriogenology. 2007; 53(9):1783-95.

15. McDonald LE. Veterinary Endocrinology and Reproduction. 3rd edn. Lea and Febiger, Philadelphia, 1980.

16. Nakao T, Sugihashi A, Kawata K, Saga N, Tsunoda N A. A further study on the doses of an analogue of luteinizing hormone releasing for treatment of ovarian follicular cyst in cows. Japanese Journal of Veterinary Science 1983a; 45:269.

17. Rao LV, Pandey RS. Radioimmunoassay of cortisol in blood of buffaloes (Bubalus bubalis) during the oestrous cycle. Cellular and Molecular Life Sciences. 1981; 37 (10):1118-19.

18. Singh JK, Ludri RS, Singh B. Cortisol levels during estrous cycle in baffaloes. Indian J Anim. Reprod. 2008; 29(1):82-85.

19. Shukla SP, Sharma RD and Jindal R. Serum estradiol and progesterone levels during estrous cycle. Indian Journal Animal Reproduction. 2000; 21(2):112-14.

20. Stevention JS. Clinical Reproductive Physiology of the Cow. (fide Youngquist 1997), 1977.

21. Tanaka M, Kamiya Y, Suzuki T, Kamiya, M, Nakai Y. Relationship between milk production and plasma concentrations of oxidative stress markers during hot season in Primiparous cows. Animal Science Journal. 2008; 79(4):481-86.

22. Walker SL, Smith RF, Jones DN, Routly E, Dobson H. Chronic stress, hormone profile and estrus intensity in dairy cattle. Hormones and Behavior. 2008; 53(3):493501. West J W. 2003. Effect of heat- stress on production in dairy cattle. Journal of Dairy Science. 2008; 86:213144.

23. West JW. Effect of heat stress on production in dairy cattle. J Dairy Sci. 2003; 86:2131-2144. 